УДК 575.174.015.3:597.552.1

\title{
ГЕНЕТИЧЕСКАЯ СТРУКТУРА ОБЫКНОВЕННОЙ ЩУКИ (ЕSOX LUCIUS L.) ИЗ РЕК СЕВЕРО-ВОСТОКА РОССИИ
}

\author{
Бачевская Л. Т., Переверзева В. В., Агапова Г. А., Примак А. А., Грунин С. И. \\ ФГБУН Институт биологических проблем Севера ДВО РАН, г. Магадан \\ E-mail: gekki54@ mail.ru
}

\begin{abstract}
Впервые получены данные о строении первичной структуры белка и изменчивости нуклеотидной последовательности гена цитохрома $b$ мтДНК обыкновенной щуки Esox lucius L. из рек Колымского и Анадырского бассейнов. Анализ матрицы нуклеотидной дивергенции гена цитохрома $b$ мтДНК обыкновенной щуки показал отличие $(\mathrm{p}<0.05)$ не только между популяциями разных регионов, но и между локальностями одного региона. Обнаружена значительная доля межгрупповой генетической изменчивости, что свидетельствует о дифференциации (несмотря на общность происхождения) популяций щуки бассейнов рр. Колыма и Анадырь. Преобладание модификации полипептида FEcb1 в исследованных выборках и в популяциях, обитающих в водоемах Евразии, указывает на то, что этот вариант полипептида, по-видимому, является наиболее функционально оптимальной формой.
\end{abstract}

Ключевые слова: обыкновенная щука Esox lucius L., ген цитохрома $b$ (Cyt-b), модификация белка цитохрома b (Cyt-b), генетический полиморфизм, филогеографический анализ.

DOI: 10.34078/1814-0998-2020-2-98-106

\section{ВВЕДЕНИЕ}

Обыкновенная щука Esox lucius Linnaeus, 1758 является типичным представителем бореального равнинного фаунистического комплекса. Она обитает в пресных водоемах Евразии и Северной Америки. Вследствие сложного рельефа СевероВостока России щука распространена мозаично, а в бассейнах крупных рек региона (Индигирка, Колыма, Анадырь, Пенжина) представлена широко (Новиков, 1966; Кириллов, 1972; Токранов, 2004; Черешнев, 2008). Биология и экология вида, обитающего в указанных реках, хорошо изучена (Берг,1949; Новиков, 1966; Кириллов, 1972; Черешнев и др., 2001; Грунин, Бакланов, 2004; Грунин, 2005, 2014; Хохлов, Хохлова, 2006; Черешнев, 2008; Грунин, Шестаков, 2011). Показано, что обыкновенная щука из рек КолымоИндигирского бассейна и р. Анадырь имеет существенные морфологические отличия (Черешнев, 1996). Экологическая приуроченность щуки к пресным водам и особенности ее распространения на Северо-Востоке России и в Чукотском автономном округе (ЧАО) позволяют использовать этот вид как биогеографический индикатор существовавших в прошлом палеогеографических

(C) Бачевская Л. Т., Переверзева В. В., Агапова Г. А., Примак А. А., Грунин С. И., 2020 связей между смежными речными бассейнами (Черешнев, 2008). Обыкновенная щука обладает способностью адаптироваться к весьма разнообразным условиям обитания. Это является важным биологическим фактором, способствующим миграции и широкому географическому расселению вида. Ранее проведенные исследования показали, что за такой экологической пластичностью могут стоять не только фенотипические, но и генетические различия. В связи с этим в последние десятилетия интенсивно развивались генетические исследования. Вначале они охватывали исключительно североамериканские популяции (Healy, Mulcahy, 1980; Seeb et al., 1987; Miller, Kapuscinski, 1996, 1997; Senanan, Kapuscinski, 2000; Miller, Senanan, 2003). В дальнейшем генетическим исследованиям подверглись популяции обыкновенной щуки из рек Европы (Hansen et al., 1999). Результаты исследований генетической изменчивости этого вида, обитающего в водоемах северо-западной части Европы, показали чрезвычайно низкий уровень его генетического разнообразия (Nicod et al., 2004). На основании результатов изучения полиморфизма микросателлитов щуки из европейских и североамериканских популяций было отмечено, что для них характерно низкое генетическое разнообразие. В то же время был обнаружен высокий уровень их дифференциации (Hansen et al., 
1999; Senanan, Kapuscinski, 2000). Молекулярногенетические исследования щуки из рек Северной Европы позволили выделить три эволюционные линии, при этом отмечена необходимость дальнейшего детального филогенетического анализа этого вида на обширном ареале (Skog et al., 2014).

Важнейшую роль в определении палеогеографических и филогеографических связей играют генетические исследования, которые до настоящего времени не охватывали популяции щуки из рек Северо-Востока России. Цель работы - изучение генетической структуры популяций щуки обыкновенной из некоторых водоемов Евразии по данным полиморфизма гена цитохрома $b$ $(C y t-b)$ мтДНК.

\section{МАТЕРИАЛ И МЕТОДЫ}

В 2015-2016 гг. был собран биологический материал (мышечная ткань) от 164 особей обыкновенной щуки. Карта-схема с указанием речных систем и точек сбора проб приведена на рис. 1. Выделение и очистку тотальной ДНК проводили фенол-хлороформным методом (Sambrook et al., 1989). Амплификацию нуклеотидной последовательности гена $C y t-b$ мтДНК щуки выполняли, используя праймеры LCbEluc 14263 (GTC ATA ATT CTT ACT CGG ACT CTA ACC) и RCbEluc15503 (CCT CCA ACT TCC GGA TTA CAA AAC CGG CGC TC), которые были разработаны в лаборатории. Условия полимеразной цепной реакции подобраны в процессе эксперимента: денатурирующая стадия $95^{\circ} \mathrm{C}-5$ мин; затем 32 цикла: $95^{\circ} \mathrm{C}-45$ c, $50^{\circ} \mathrm{C}-30$ c, $70^{\circ} \mathrm{C}-2$ мин $30 \mathrm{c}$; заключительная стадия $-72^{\circ} \mathrm{C}-$ 7 мин. Амплифицированный участок мтДНК очищали и подготавливали к секвенированию по стандартной методике с применением набоpa реагентов Diatom ${ }^{\mathrm{TM}}$ DNA Clean-Up («Лаборатория Изоген», г. Москва). Определение нуклеотидных последовательностей исследуемого гена $C y t-b$ мтДНК было проведено по стандартной методике с использованием наборов для циклического секвенирования ДНК Big Dye Terminator (Applied Biosystems, v. 3.1) и генетического анализатора ABI Prism 3130 (Applied Biosystems, США). Полученные нуклеотидные последовательности были депонированы в GenBank. Их выравнивание и анализ проводили с помощью пакета программ MEGA 6.0.2.74 (Tamura et al., 2013) и ARLEQUIN ver. 3.5 (Excoffier et al., 2005). Филогеографический анализ выполняли с ис- пользованием дистанционно-матричного алгоритма neighbor-joining (NJ). Для него была выбрана бипараметрическая модель дистанции Кимуры, учитывающая длину анализируемого участка мтДНК и разные вероятности транзиций/трансверсий в исследуемом гене ( $\mathrm{Nei}, \mathrm{Ku}-$ mar, 2000; Лукашов, 2009; Tamura et al., 2013). Для этого были привлечены сведения о строении нуклеотидных последовательностей гена $c y t b$ мтДНК обыкновенной щуки из GenBank, представленные в нескольких публикациях (Grande et al., 2004; Skog et al., 2014). Оценку узлов ветвления NJ-дерева осуществляли методом бутстреп (1000 итераций) в программе POPTREE (Takezaki et al., 2014). С помощью модели MM01 в программе TreeSAAP 3.2 анализировали характер изменений физикохимических свойств белка Cyt-b в ходе эволюции (Woolley et al., 2003). Указанная программа (опираясь на предположение о случайном характере аминокислотных замен в условиях селективной нейтральности) дает возможность сопоставлять наблюдаемое и ожидаемое распределения изменений физико-химических свойств модификаций Cyt-b на филогенетическом дереве гаплотипов мтДНК. Оценку значимости аминокислотных замен и типа отбора проводили с использованием Z-теста модели MM01 (где z - значимость аминокислотных замен по Фишеру, mс - категория значимости) в программе TreeSAAP 3.2 (Woolley et al., 2003).

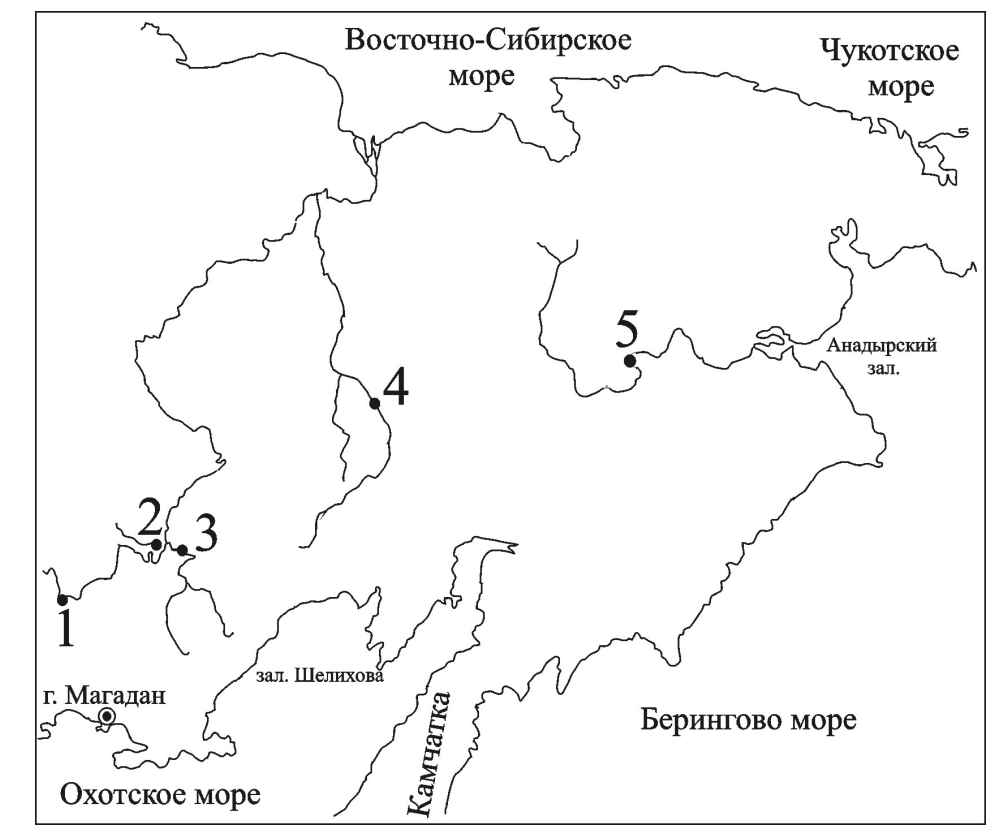

Рис. 1. Карта-схема точек сбора материала: 1 - р. Колыма, 2 р. Эльген, 3 - р. Буюнда, 4 - р. Омолон, 5 - р. Анадырь

Fig.1. Schematic map of the collection area: 1 - Kolyma River, 2 - Elgen River, 3 - Buyunda River, 4 - Omolon River, 5 - Anadyr River 


\section{РЕЗУЛЬТАТЫ И ОБСУЖДЕНИЕ}

Изученный ген $C y t-b$ мтДНК обыкновенной щуки содержит 1140 пар нуклеотидов (пн) и соответствует положению в участке 14341-15477 пн полного генома мтДНК обыкновенной щуки E. lucius L., GenBank, NC004593 (Ishiguro et al., 2003). У щуки обыкновенной из рр. Эльген, Буюнда, Омолон, Анадырь и верховьев Колымы обнаружено небольшое число вариабельных позиций от общей длины гена $C y t-b$ мтДНК $(0.44 \%)$. С учетом представленных в GenBank образцов нуклеотидных последовательностей щуки обыкновенной (рис. 2) их число значительно возросло и составило $1.75 \%$. Среднее число попарных различий между нуклеотидными последовательностями гена $C y t-b$ мтДНК щуки coставило $0.3 \%$, однако интервал различий достаточно широк $-0.1-0.8 \%$ (рассчитано с помощью программы MEGA 6.0.2.74) (Tamura et al., 2013).

\begin{tabular}{|c|c|}
\hline & 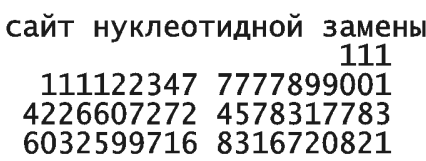 \\
\hline Cyt-b-гаплотипы & 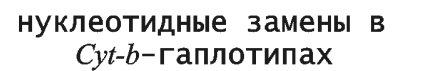 \\
\hline KT203375, Ecb1 & GCGTCGCCGA CATGGACGTA \\
\hline $\begin{array}{ll}\text { KT203376, } & \text { Ecb2 } \\
\text { KT203377, } & \text { Ecb3 }\end{array}$ & 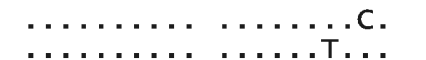 \\
\hline KT203378, Ecb4 & ... \\
\hline KT203379, ECb5 & $. G \ldots . .$. \\
\hline KU659805, Ecb6 & $\ldots \ldots \ldots G \ldots$ \\
\hline $\begin{array}{l}\text { AY497452 p. Нева } \\
\text { КM281466 р. Таз }\end{array}$ & \#T.T.A. T. .AC. . \\
\hline $\begin{array}{l}\text { KM281466 p. Таз } \\
\text { KM281465 p. Таз }\end{array}$ & 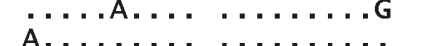 \\
\hline КM281464 р. Урал & $\ldots \ldots \ldots$ \\
\hline КМ281461 р. Урал &.$T \ldots \ldots$. \\
\hline КМ281460 р. Урал & $\ldots{ }_{1} \ldots \ldots$ \\
\hline КМ281476 р. волга & .A.T..T. T.C.AC... \\
\hline $\begin{array}{l}\text { КM281469 p. Анадырь } \\
\text { КМ281470 p. Анадырь }\end{array}$ & $\ldots \ldots \ldots \ldots$ \\
\hline (M2814/0 р. Анадырь & $\ldots \ldots \ldots$ \\
\hline
\end{tabular}

Puc. 2. Нуклеотидные последовательности гена цитохрома $b$ мтДНК обыкновенной щуки из рек СевероВостока России и варианты, депонированные в GenBank. Сайты замен показаны от начала гена $C y t-b$ мТДНК

Fig. 2. Nucleotide sequences of the mtDNA cytochrome $b$ gene in the northern pike from the rivers of Russia's North-East and the variants deposited in GenBank. Replacement sites are shown from the start of the mtDNA $c y t-b$ gene

В нуклеотидном составе исследованного гена $C y t-b$ мтДНК обыкновенной щуки из Колымского и Анадырского бассейнов обнаружено смещение в сторону тимина и аденина (30.26 и $25.86 \%$ соответственно) относительно цитозина и гуанина (29.75 и $14.04 \%$ соответственно). С использованием критерия $\chi$-квадрат было обнаружено статистически достоверное $\left(\chi^{2}=4.08 ; \mathrm{p}<0.05\right)$ отклонение соотношения (60.01:39.9) пуринов и пиримидинов от ожидаемого 1:1. Отклонение в соотношении пар A-T и $\mathrm{G}-\mathrm{C}$ не обнаружено. Полученные результаты согласуются с гипотезой о необходимости поддержания за этот счет гидрофобности соответствующих полипептидов (Nailor et al., 1996; Kim et al., 2004; Kartavtsev et al., 2007; Картавцев, 2013).

Анализ полученных нами нуклеотидных последовательностей гена $C y t-b$ мтДНК щуки из исследованных локальностей позволил выявить шесть вариантов (Есв1 - Есв6) гена $C y t-b$ (см. рис. 2), которые депонированы в GenBank (KT203375 - KT203379, KU659805). Выборки из рр. Буюнда, Эльген и Колыма - мономорфны по изученному маркеру. Они были представлены особями-носителями гаплотипа КТ203375, Ecb1 гена $C y t-b$ (табл. 1).

Необходимо обратить внимание на то, что у обыкновенной щуки из р. Омолон обнаружен мономорфизм по гаплотипу Ecb6 (KU659805) указанного гена. Этот гаплотип встречается только в омолонской популяции вида. Щука из р. Анадырь обладает более высоким уровнем генетического разнообразия. В выборке из данной локальности выявлено пять из шести гаплотипов, встречающихся в исследованных популяциях (см. табл. 1). Анализ генетической изменчивости показал, что анадырская выборка характеризовалась следующими значениями гаплотипического $(h=0.5204 \pm 0.0763)$ и нуклеотидного $(\pi=0.000519 \pm 0.000470)$ разнообразия. Выборки из рек Колымского бассейна в целом имеют более низкие значения обоих параметров ( $h=$ $0.2157 \pm 0.0462 ; \pi=0.00019 \pm 0.000255)$, чем в анадырской популяции. Обнаруженная особенность весьма интересна, так как принято считать, что щука обыкновенная из р. Колыма в процессе расширения ареала проникла в р. Анадырь (Черешнев, 1986). Известно, что при расселении вида возможно снижение уровня генетического разнообразия. Однако мы наблюдаем обратную картину. Возможно, это объясняется относительной стабильностью анадырской популяции обыкновенной щуки (при высокой численности) на протяжении длительного исторического периода существования, в то время как щука из р. Колыма и ее притоков утратила генетическое разнообразие в процессе становления этого бассейна. Известно, что он имел очень сложную историю формирования (Баранова, Бискэ, 1964; Байрон и др., 1977).

Восстановление генетического разнообразия щуки из рек Колымского бассейна в дальнейшем за счет мигрантов из сибирских рек было невозможным. С конца плиоцена и, вероятно, до позднечетвертичного времени обмен фаунами между реками Восточной Сибири и КолымоИндигирской низменности был затруднен, так как существовал водораздел, образованный Новосибирскими островами (Баранова, Бискэ, 1964). На 
основании принятых для этих районов датировок фаз тектонической активизации в четвертичном периоде было выделено пять этапов развития Колымской низменности в позднем кайнозое. Отмечено, что лишь в голоцене завершился процесс формирования рельефа северо-восточной части низменности и дельты р. Колыма (Байрон и др., 1977). Учитывая этот факт, можно предположить, что в истории формирования популяций щуки из рек Колымского бассейна неоднократно происходили изменения их генетической структуры. Очевидно, что значительное влияние на их генетическое разнообразие имел эффект «горлышка бутылки» (Nei, 1987). В период восстановления популяций от небольшого числа особей вследствие стохастических процессов (дрейф генов) могла произойти утрата ряда гаплотипов, что, возможно, привело к существенному снижению уровня генетического разнообразия. Наблюдаемый нами низкий уровень генетического разнообразия в выборках из Колымского бассейна, вероятно, еще более усиливается демографическими особенностями щук, которые, как и многие другие хищники, имеют низкий эффективный размер популяции (Miller, Kapuscinski, 1997). Нами был рассчитан популяционный параметр изменчивости $\left(\theta_{\mathrm{k}}\right)$, который отражает эффективный размер популяций (Excoffier et al., 2005). Полученные данные показывают, что анадырская и колымская локальности обыкновенной щуки отличаются по этому параметру практически на порядок $\left(\theta_{\mathrm{k}}=1.187\right.$ и 0.198 соответственно).

В процессе генетического анализа оценена значимость различий по нуклеотидным заменам в сравниваемых парах исследованных популяций обыкновенной щуки (Excoffier et al., 2005).
Анализ матрицы нуклеотидной дивергенции мтДНК исследованных выборок щуки показал, что различие $(\mathrm{p}<0.05)$ наблюдается между популяциями разных регионов и между локальностями одного региона (см. табл. 2). Полученные данные анализировали с использованием алгоритма neighbor-joining. Этот метод позволяет корректно реконструировать филогенетические деревья при сравнении близкородственных популяций (Saitou, Imanishi, 1989). Дендрограмма построена на основании алгоритмической аппроксимации дерева минимальной эволюции. Результаты кластерного анализа позволили выделить на дендрограмме (рис. 3) два кластера. Они имеют высокий уровень бутстреп-поддержки (70 и 99\%). Первый кластер структурирован и наиболее широко представлен географически. Во второй кластер входят популяции щуки из рр. Волга и Нева (см. рис. 3). Отмеченная структурированность кластеров была использована при выделении групп популяций для проведения анализа с использованием методики «AMOVA» Analysis of Molecular Variance (Excoffier et al., 2005).

Таблица 2. Генетические различия между парами исследованных популяций обыкновенной щуки из некоторых рек Евразии

Table 2. Genetic differences between pairs of the studied northern pike populations from some rivers in Eurasia

\begin{tabular}{|l|c|c|c|c|c|c|c|c|c|}
\hline \multicolumn{1}{|c}{ № , река } & 1 & 2 & 3 & 4 & 5 & 6 & 7 & 8 & 9 \\
\hline 1. Анадырь & - & $\mathbf{0 . 0 0} \pm \mathbf{0 . 0 0}$ & $\mathbf{0 . 0 0} \pm \mathbf{0 . 0 0}$ & $\mathbf{0 . 0 0} \pm \mathbf{0 . 0 0}$ & $\mathbf{0 . 0 0} \pm \mathbf{0 . 0 0}$ & $0.991 \pm 0.003$ & $0.991 \pm 0.003$ & $\mathbf{0 . 0 0 9} \pm \mathbf{0 . 0 0 1}$ & $\mathbf{0 . 0 3 6} \pm \mathbf{0 . 0 2 0}$ \\
\hline 2. Буюнда & 0.091 & - & $0.991 \pm 0.003$ & $\mathbf{0 . 0 0} \pm \mathbf{0 . 0 0}$ & $0.991 \pm 0.003$ & $0.991 \pm 0.003$ & $0.991 \pm 0.003$ & $\mathbf{0 . 0 0} \pm \mathbf{0 . 0 0}$ & $\mathbf{0 . 0 0} \pm \mathbf{0 . 0 0}$ \\
\hline 3. Колыма & 0.073 & 0 & - & $\mathbf{0 . 0 0} \pm \mathbf{0 . 0 0}$ & $0.991 \pm 0.003$ & $0.991 \pm 0.003$ & $0.991 \pm 0.003$ & $\mathbf{0 . 0 0} \pm \mathbf{0 . 0 0}$ & $\mathbf{0 . 0 0} \pm \mathbf{0 . 0 0}$ \\
\hline 4. Омолон & 0.670 & 1.00 & 1.00 & - & $\mathbf{0 . 0 0} \pm \mathbf{0 . 0 0}$ & $0.991 \pm 0.003$ & $0.991 \pm 0.003$ & $\mathbf{0 . 0 2 7} \pm \mathbf{0 . 0 1 4}$ & $\mathbf{0 . 0 0} \pm \mathbf{0 . 0 0}$ \\
\hline 5. Эльген & 0.072 & 0 & 0 & 1.00 & - & $0.991 \pm 0.003$ & $0.991 \pm 0.003$ & $\mathbf{0 . 0 0} \pm \mathbf{0 . 0 0}$ & $\mathbf{0 . 0 0} \pm \mathbf{0 . 0 0}$ \\
\hline 6. Нева & 0.900 & 1.00 & 1.00 & 1.00 & 1.00 & - & $0.991 \pm 0.003$ & $0.297 \pm 0.036$ & $0.207 \pm 0.033$ \\
\hline 7. Волга & 0.914 & 1.00 & 1.00 & 1.00 & 1.00 & 1.00 & - & $0.270 \pm 0.033$ & $0.288 \pm 0.042$ \\
\hline 8. Таз & 0.475 & 0.911 & 0.879 & 0.887 & 0.875 & 0.600 & 0.647 & - & $0.378 \pm 0.040$ \\
\hline 9. Урал & 0.271 & 0.773 & 0.706 & 0.828 & 0.698 & 0.714 & 0.750 & 0.046 & - \\
\hline
\end{tabular}

Примечание. Под диагональю - значения FST при попарном сравнении популяций, над диагональю - уровни значимости различий между популяциями щуки. Жирным шрифтом обозначены статистически значимые различия между парами популяций $(\mathrm{p}<0.05)$. 


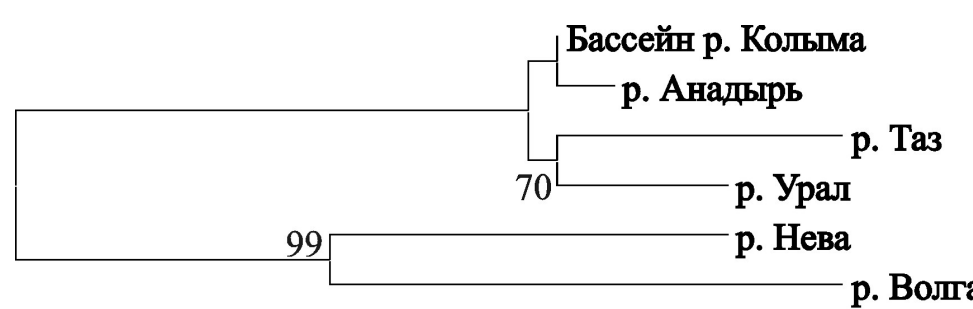

\subsection{5}

Puc. 3. Филогенетические взаимоотношения популяций обыкновенной щуки из некоторых рек Евразии. NJ-дендрограмма (масштабный отрезок соответствует числу нуклеотидных замен на один сайт)

Fig. 3. Phylogenetic relationships among populations of the northern pike from some rivers of Eurasia. NJ-dendrogram (scale segment corresponds to the number of nucleotide substitutions per site)

В первую группу включили все нуклеотидные последовательности гена $C y t$ - $b$ мтДНК обыкновенной щуки из рек Колымского бассейна. Во вторую объединили все гаплотипы, характеризующие выборку из р. Анадырь. В третью группу вошли популяции из рр. Урал и Таз, а в четвертую - из рр. Нева и Волга. При таком варианте объединения доля межгрупповой генетической изменчивости была невелика и составила $31 \%$, а внутригрупповая доля - 91\%. Подобный анализ был проведен с выделением двух групп, в которые были включены только исследованные нами популяции. В первую группу вошли все локальности Колымского бассейна, во вторую щука из р. Анадырь. Результаты показали, что в этом случае доля межгрупповой генетической изменчивости была более значительной и составила $59.38 \%$. Вполне вероятно, что отмеченный нами факт связан с геологическим прошлым этого региона. Известно, что определяющую роль в изменении сложившегося бореально-равнинного комплекса сыграли трансгрессии океана, уничтожавшие пресноводную фауну в равнинных участках рек, и регрессии, способствующие вторичному ее расселению из убежищ. Во время максимальной (предпредпоследней) трансгрессии, по-видимому, были затоплены долины многих рек, в том числе рр. Омолон и Колыма, что привело к утрате биологического разнообразия их пресноводной фауны. В то же время предполагается, что в плиоцен-раннечетвертичную эпоху в пределах Среднесибирского плоскогорья существовал обширный пресноводный водоем, который и служил убежищем для водной равнинной фауны (Лунгерсгаузен, 1961; Жуков и др., 1966). Пути расселения пресноводных рыб пролегали не только через единые древние шельфовые речные системы Берингии. В периоды интенсивного вулканизма и сейсмической активности возникали перехваты близкорасположенных смежных вер- ховьев рек, благодаря которым происходило проникновение видов в новые речные бассейны (Черешнев, 2008). Предположительно в позднем плиоцене щука вселилась в р. Анадырь из р. Колыма через перехваты верховьев этих рек (Черешнев, 1998). Проникновение щуки в р. Анадырь в более поздний период не могло осуществиться, так как связи p. Колыма с реками Чукотки прекратились (восточнее м. Биллингса) и более не возобновлялись. По-видимому, обнаруженная нами значительная доля межгрупповой изменчивости обыкновенной щуки из исследованных локальностей обусловлена длительным периодом их изоляции. В то же время преобладание одного общего гаплотипа Ecb1 гена $C y t-b$ мтДНК в выборках щуки из рек Колымского бассейна и р. Анадырь свидетельствует о том, что они имеют общность происхождения. В истории становления популяций из Колымского бассейна в целом большое значение, по-видимому, имело такое событие, как постледниковая реколонизация из небольшого числа убежищ от ограниченного числа основателей.

Проведенный ранее сравнительный анализ строения молекулы белка Cyt-b некоторых видов животных показал, что трансмембранные домены этого полипептида наиболее вариабельны, а самыми консервативными являются петлевые участки Qo редокс-центра Cyt-b. B то же время было отмечено, что большинство вариаций в трансмембранной части Cyt-b не изменяют его функциональности (Howell, 1989; Irwin et al., 1991; McClellan et al., 2005). При исследовании первичной структуры белка Cyt-b обыкновенной щуки из рек Колымского и Анадырского бассейнов были обнаружены три варианта полипептида Cyt-b (рис. 4).

Гаплотипы Ecb1, Ecb3, Ecb5, Ecb6 кодируют вариант белка Cyt-b FEcb1, распространенного во всех исследованных колымских и анадырской популяциях вида. Гаплотип Ecb2 кодирует FEcb2, а гаплотип Ecb4 - FEcb3. Эти варианты исследованного полипептида уникальны, так как обнаружены только в анадырской популяции щуки. Модификация белка FEcb1 распространена не только у обыкновенной щуки из рек исследованного региона, но и широко представлена у особей вида, обитающих в водоемах Евразии (Skog et al., 2014). Вероятно, этот вариант белка является наиболее функционально оптимальной модификацией. Его преобладание у обыкновенной щуки из исследованных нами популяций, а также обитающей в реках Европы и Сибири (GenBank), по-видимому, обусловлено общностью их происхождения. 


\begin{tabular}{|c|c|}
\hline модификация & $\begin{array}{l}\quad 33 \\
1766 \\
6001 \\
\text { полипептида } \\
\text { Суtb }\end{array}$ \\
\hline $\begin{array}{l}\text { cytb-гаплотипы } \\
\text { кT203375, Есb1 }\end{array}$ & $\begin{array}{l}\text { FEcb1 } \\
\text { DCAI }\end{array}$ \\
\hline $\begin{array}{ll}\text { KT203377, } & \text { Ecb3 } \\
\text { KT203379, } & \text { Ecb5 }\end{array}$ & $\cdots$ \\
\hline KU659805, Ecb6 & $\because \cdots$ \\
\hline AY497452 р. Нева & $\ldots$ \\
\hline КМ281460 р. Урал & $\ldots$ \\
\hline КМ281461 р. Урал & $\ldots$ \\
\hline KM281464 р. Урал & $\cdots$ \\
\hline КМ281476 р. Волга & $\cdots$ \\
\hline $\begin{array}{l}\text { КT203376, Есb2 } \\
\text { КМ281469 р. Анадырь }\end{array}$ & $\begin{array}{l}\text { FEcb2 } \\
\ldots \text { T } \\
\ldots \text { T }\end{array}$ \\
\hline $\begin{array}{l}\text { КT203378, Есb4 } \\
\text { КM281470 р. Анадырь }\end{array}$ & $\begin{array}{l}\text { FEcb3 } \\
\because \mathrm{T} \\
\because \mathrm{T}\end{array}$ \\
\hline KM281465 p. Таз & $\begin{array}{l}\text { FEcb4 } \\
\text { N... }\end{array}$ \\
\hline КM281466 р. Таз & $\begin{array}{l}\text { FEcb5 } \\
\text {.Y... }\end{array}$ \\
\hline
\end{tabular}

Puc. 4. Аминокислотные замены в модификациях (FEcb1 - FEcb6) полипептида Cyt-b у обыкновенной щуки из некоторых рек Евразии. Цифрами обозначены сайты замен от начала полной аминокислотной последовательности белка Cyt-b F1

Fig. 4. Aminoacid substitutions in the Cyt-b polypeptide modifications (FEcb1 - FEcb6) in the northern pike from some rivers in Eurasia. Numerals denote replacement sites from the beginning of the complete amino-acid sequence of the Cyt-b F1 protein

Анализ строения молекулы белка Cyt-b позволил отметить замены (А360T и I361T) в аминокислотной последовательности Cyt-b, которые находятся в трансмембранном домене. Фиксация замены аминокислоты в определенной позиции белка возможна лишь в том случае, если его активность сохранится на уровне, необходимом для обеспечения жизнедеятельности организма. Следовательно, можно предположить, что данные аминокислотные замены функционально синонимичны.

Для сравнительного анализа полученных результатов и представленных ранее были привлечены из GenBank образцы нуклеотидных последовательностей гена $C y t-b$ щуки обыкновенной: АY 497452, КМ281460, КМ281461, KM281464-KM281466, KM281469, KM281470, KM281476 (Grande et al., 2004; Skog et al., 2014). Их анализ показал, что вариабельные сайты обнаружены не только в пределах трансмембранных доменов белка Cyt-b обыкновенной щуки, но и в окислительновосстановительных центрах фермента. В целом у обыкновенной щуки отмечены аминокислотные замены (см. рис. 4) в следующих позици- яx: D16N, C70Y, A360T и I361T. Для определения характера изменений физико-химических свойств аминокислот в ходе эволюции были использованы методы Снита, Бачинского и Грэнтсема (Grantham, 1974; Бутвиловский и др., 2009). С помощью этих методов показано, что аминокислотная замена С70Y (образец KM281466, p. Таз) определяется как радикальная, резко изменяющая свойства белка. Заменяемые аминокислоты (цистеин и тирозин) имеют близкие значения изоэлектрических точек - 5.02 и 5.66, обладают низкой растворимостью - 0.01 и 0.05 г/100 г воды, но значимо различаются по молекулярной массе радикалов - 61 и 107 соответственно. В то же время для определения характера обнаруженных аминокислотных замен, обусловленного степенью радикальности или консервативности каждой из них, был использован Z-тест модели MM01 в программе TreeSAAP 3.2 (Woolley et al., 2003). Результаты проведенного TreeSAAP-анализа $(\mathrm{z}>3.09, \mathrm{p}<0.001, \mathrm{mc}=6)$ показали только одну замену D16N (образец KM281465, p. Таз), которая могла возникнуть и закрепиться под действием положительного вектора направленного отбора (McClellan et al., 2005). Аминокислотные замены, поддерживаемые такого рода отбором, по-видимому, являются результатом молекулярной адаптации вида в изменчивых условиях существования.

Работа выполнена при частичной финансовой поддержке ДВО РАН (грант № 15-I-6-015о) и РФФИ (грант № 15-04-01418).

\section{ЛИТЕРАТУРА}

Байрон И. Ю., Миллер В. Г., Минченок В. Д. Развитие низовьев р. Колымы в плейстоцене // Геоморфология. 1977. № 2. С. 44-51.

Баранова Ю. П., Бискэ С. Ф. Северо-Восток СССР. М. : Наука, 1964. 350 с.

Берг Л. С. Рыбы пресных вод СССР и сопредельных стран. М. ; Л. : Изд-во АН СССР, 1949. Ч. 2. C. 469-925.

Бутвиловский А. В., Барковский Е. В., Бутвиловский В. Э., Давылов В. В., Черноус Е. А., Хрусталев $B$. $B$. Основные методы молекулярной эволюции / под общ. ред. проф. Е. В. Барковского. Минск : Белпринт, 2009. 216 c.

Грунин С. И. Динамика популяционных показателей щуки Esox lucius L. (Esocidae) p. Анадырь за период 1971-2010 гг. // Известия ТИНРО. 2014. Т. 179. C. $45-54$.

Грунин С. И. Изменение биологической структуры популяции обыкновенной щуки Esox lucius L. среднего течения р. Анадырь в условиях воздействия промысла разной интенсивности // Вестник СВНЦ ДВО PAH. 2005. № 3. C. 92-95.

Грунин С. И., Бакланов М. А. Размерная изменчивость внешнеморфологических признаков сеголетков щуки Esox lucius L. // Вестник Перм. гос. ун-та. 2004. Вып. 2. Биология. С. 99-101. 
Грунин С. И., Шестаков А. В. Современное состояние популяции щуки Esox lucius L. среднего течения p. Анадырь (Чукотка) // Вопросы рыболовства. 2011. T. 12, № 3. C. 457-471.

Жуков В. В., Пинчук Л. Я., Пуминов А. П. Палеогеография Северо-Востока Средне-Сибирского плоскогорья и Лено-Анадырской низменности в кайнозое // Четвертичный период Сибири. М.: Наука, 1966. С. 264-272.

Картавиев Ю. Ф. Генетическая дивергенция видов и других таксонов. Географическое видообразование и генетическая парадигма неодарвинизма в действии // Успехи совр. биологии. 2013. Т. 133, № 5. C. 419-451.

Кириллов Ф. Я. Рыбы Якутии. М. : Наука, 1972. 358 с.

Лукашов В. В. Молекулярная эволюция и филогенетический анализ. М. : БИНОМ. Лаборатория знаний, 2009. 256 с.

Лунгерсгаузен Г. Ф. Геологическая история Средней Лены и некоторые вопросы стратиграфии четвертичных отложений Восточной Сибири : Материалы Всесоюз. совещ. по изучению четвертич. периода. М. : Изд-во АН СССР, 1961. Ч. 3. С. 209-217.

Новиков А. С. Рыбы реки Колымы. М. : Наука, 1966. $135 \mathrm{c}$.

Токранов A. M. О «бесчешуйном звере» и других обитателях камчатских вод. П.-Камчатский : КамчатНИРО, 2004. 152 с.

Хохлов Ю. Н., Хохлова Ю. Е. Особенности питания обыкновенной щуки Esox lucius L. в среднем течении p. Анадырь в осенний период // Вестник СВНЦ ДВО PAH. 2006. № 2. С. 54-58.

Черешнев И. А. Биогеография пресноводных рыб Дальнего Востока России. Владивосток : Дальнаука, 1998. $131 \mathrm{c}$.

Черешнев И. А. Биологическое разнообразие пресноводной ихтиофауны Северо-Востока России. Владивосток : Дальнаука, 1996. 198 с.

Черешнев И. А., Шестаков А. В., Скопец М. Б. Определитель пресноводных рыб Северо-Востока России. Владивосток : Дальнаука, 2001, 129 с.

Черешнев И. А. Пресноводные рыбы Чукотки. Магадан : СВНЦ ДВО РАН, 2008. 324 с.

Черешнев И. А. Происхождение пресноводной ихтиофауны районов Берингии // Биогеография Берингийского сектора Субарктики. Владивосток : Изд-во ДВНЦ АН СССР, 1986. С. 122-145.

Excoffier L., Laval G., Schneider S. Arlequin ver. 3.0: An integrated software package for population genetics data analysis // Evol. Bioinform. Online. 2005. Vol. 1. P. 47-50.

Grande T., Laten H., Lopez J. A. Phylogenetic relationships of extant esocid species (Teleostei: Salmoniformes) based on morphological and molecular characters // Copeia. 2004. Vol. 4. P. 743-757.

Grantham R. Amino acid difference formula to help explain protein evolution // Science. 1974. Vol. 185, No. 4154. P. 862-864.

Hansen M. M., Taggart J. B., Meldrup D. Development of new VNTR markers for pike and assessment of variability at di- and tetranucleotide repeat microsatellite loci // J. Fish. Biol. 1999. Vol. 55. P. 183-188.

Healy J. A., Mulcahy M. F. A biochemical genetic analysis of populations of the northern pike, Esox lucius L., from Europe and North America // Ibid. 1980. Vol. 17. P. 317-324.
Howell N. Evolutionary conservation of protein regions in the proton motive cytochrome $b$ and their possible roles in redox catalysis // J. Mol. Evol. 1989. Vol. 29. P. 157-169.

Irwin D. M., Kocher T. D., Wilson A. C. Evolution of the cytochrome $b$ gene of mammals // Ibid. 1991. Vol. 32 . P. $128-144$.

Ishiguro N. B., Miya M., Nishida M. Basal euteleostean relationships: a mitogenomic perspective on the phylogenetic reality of the "Protacanthopterygii" // Mol. Phylogenet. Evol. 2003. Vol. 27, No. 3. P. 476-488.

Kartavtsev Y. Ph., Park T.-J., Vinnikov K. A., Ivankov $V$. N., Sharina S. N., Lee J.-S. Cytochrome b (Cyt-b) gene sequence analysis in six flatfish species (Teleostei, Pleuronectidae), with phylogenetic and taxonomic insights // Marine Biology. 2007. Vol. 152. P. 757-773.

Kim H. S., Choi E. S., Shin J. A., Jang Y. K., Park S. D. Regulation of Swi6/HPl-dependent heterochromatin assembly by cooperation of components of the mitogen-activated protein kinase pathway and a histone deacetylase Clr6 // J. Biol. Chem. 2004. Vol. 279. P. 42850-42859.

McClellan D. A., Palfreyman E. J., Smith M. J., Moss J. L., Christensen R. G., Sailsbery J. K. Physicochemical evolution and molecular adaptation of the cetacean and artiodactyl cytochrome b proteins // Mol. Biol. Evol. 2005. Vol. 22. P. 437-455.

Miller L. M., Senanan $W$. A review of northern pike population genetics research and its implications for management // North Am. J. Fish Managem. 2003. No. 23. P. 297-306.

Miller L. M., Kapuscinski A. R. Historical analysis of genetic variation reveals low effective population size in a northern pike (Esox lucius) population // Genetics. 1997. Vol. 147. P. 1249-1258.

Miller L. M., Kapuscinski A. R. Notes: microsatellite DNA markers reveal new jevels of genetic variation in northern pike // Trans. Am. Fish Soc. 1996. Vol. 125. P. 971-977.

Naylor G. J., Collins T. M., Brown W. M. Hydrophobicity and phylogeny // Nature. 1996. Vol. 373. P. 565-566.

Nei M., Kumar S. Molecular evolution and phylogenetic. N. Y. : Oxford Univ. Press, 2000. 333 p.

Nei M. Molecular evolutionary genetics. N. Y.: Columb. Univ. Press, 1987. 512 p.

Nicod J. C., Wang Y. Z., Excoffier L., Largiadèr C. R. Low levels of mitochondrial DNA variation among central and southern European Esox lucius populations // J. Fish Biol. 2004. Vol. 64. P. 1442-1449.

Saitou N., Imanishi T. Relative efficiencies of the FitchMargoliash, maximum-parsimony, maximum-likelihood, maximum-evolution, and neighbor-joining methods of phylogenetic tree construction in obstraining the correct tree // Mol. Biol. Evol. 1989. Vol. 6. P. 514-525.

Sambrook J., Fritschi E. F., Maniatis T. Molecular cloning: a laboratory manual, Cold Spring Harbor Laboratory Press. New York, 1989. P. 524-531.

Seeb J. E., Seeb L. W., Oates D. W., Utter F. M. Genetic variation and postglacial of populations of northern pike (Esox lucius) in North America // Can. J. Fish Aquat. Sci. 1987. Vol. 44. P. 556-561.

Senanan W., Kapuscinski A. R. Genetic relationships among populations of northern pike (Esox lucius) // Ibid. 2000. Vol. 57. P. 391-404.

Skog A., Vollestad L. A., Stenseth N. C., Kasumyan A. O., Jakobsen K. S. Circumpolar phylogeography of the northern pike (Esox lucius) and its relationship to the 
Amur pike (E. reichertii) // Frontiers Zool. 2014.11:67. http://www.frontiersinzoology. com/content/11/1/67

Takezaki N., Nei M., Tamura K. POPTREEW: Web Version of POPTREE for Constructing Population Trees from Allele Frequency Data and Computing Some Other Quantities // Mol. Biol. Evol. 2014. No. 31 (6). P. 1622 1624.

Поступила в редакиию 12.11.2018 2.

Поступила после доработки 06.03.2019 г.
Tamura K., Stecher G., Peterson D., Filipski A., Kumar S., MEGA-6: Molecular Evolutionary Genetics Analysis Version 6.0.2.74 // Ibid. 2013. Vol. 30. P. 27252729.

Woolley S., Johnson M. J., Smith M. J. TreeSAAP: selection on amino acid properties using phylogenetic trees // Bioinformatics. 2003. Vol. 19, No. 5. P. 671-672.

\title{
GENETIC STRUCTURE OF THE NORTHERN PIKE (ESOX LUCIUS L.) FROM RIVERS IN RUSSIA'S NORTH-EAST
}

\author{
L. T. Bachevskaya, V. V. Pereverzeva, G. A. Agapova, A. A. Primak, S. I. Grunin \\ Institute of Biological Problems of the North, FEB RAS, Magadan
}

\begin{abstract}
Data on the composition of the primary protein structure and the nucleotide sequence variability of the mtDNA cytochrome b gene of the northern pike Esox lucius L. from the rivers of the Kolyma and Anadyr basins were obtained for the first time. Analysis of the matrix of nucleotide divergence of the cytochrome $b$ gene of mtDNA of the northern pike showed a difference $(p<0.05)$ not only among populations in different regions, but also among the localities in one region. A significant proportion of intergroup genetic variability was found, which indicates the differentiation (despite the common origin) of the pike populations in the Kolyma and Anadyr basins. The predominance of modification of the FEcb1 polypeptide in the studied samples and in populations living in Eurasian water bodies indicates that this variant of the protein is, functionally, the most optimal form.
\end{abstract}

Keywords: northern pike Esox lucius, citochrome $b(C y t-b)$ gene, modification of citochrome b (Cyt-b) gene protein, genetic polymorphism, phylogeographic analysis.

\section{REFERENCES}

Baranova, Yu. P.; Biske, S. F., 1964, North-East of the USSR, Moscow, Nauka [In Russian].

Bayron, I. Yu.; Miller, V. G.; Minchenok, V. D., 1977, Development of the Lower Reaches of the Kolyma R. in Pleistocene, Geomorphology, 2, 44-51 [In Russian].

Berg, L. S., 1949, Fishes of the USSR's and the Adjacent Countries' Fresh Waters, Moscow, Leningrad, AS USSR, Part 2, 469-925 [In Russian].

Butvilovsky, A.V.; Barkovsky, E. V.; Butvilovsky, V.E.; Davydov, V. V.; Chernous, Ye. A.; Khrustalyov, V. V., 2009, Basic Methods of Molecular Evolution, Ed. Ye. V. Barkovsky, Minsk, Belprint [In Russian].

Chereshnev, I. A., 1986, Origin of the Freshwater Ichthyofauna in the Beringian Areas, Biogeography of the Beringian Subarctic Sector, Vladivostok, FESC AS USSR, 122-145 [In Russian].

Chereshnev, I. A., 1996, Biological Diversity of Freshwater Ichthyofauna in the North-East of Russia, Vladivostok, Dalnauka [In Russian].

Chereshnev, I. A., 1998, Biogeography of Freshwater Fish in Russia's Far East, Vladivostok, Dalnauka [In Russian].

Chereshnev, I. A., 2008, Freshwater Fishes of Chukotka, Magadan, NESC FEB RAS [In Russian].

Chereshnev, I. A.; Shestakov, A. V.; Skopets, M. B., 2001, Identification Guide of Freshwater Fishes in Russia's North-East, Vladivostok, Dalnauka [In Russian].
Excoffier, L.; Laval, G.; Schneider, S., 2005, Arlequin ver. 3.0: an Integrated Software Package for Population Genetics Data Analysis, Evol. Bioinform., Online, 1, 4750 .

Fleming, M. A.; Cook, J. A., 2002, Phylogeography of Endemic Ermine (Mustela erminea) in Aoutheast Alaska, Mol. Ecol., 11, 795-807.

Grande, T.; Laten, H.; Lopez, J. A., 2004, Phylogenetic Relationships of Extant Esocid Species (Teleostei: Salmoniformes) Based on Morphological and Molecular Characters, Copeia, 4, 743-757.

Grantham, R., 1974, Amino Acid Difference Formula to Help Explain Protein Evolution, Science, 185, 4154, 862-864.

Grunin, S. I., 2005, Changes in the Biological Structure of the Northern Pike Esox lucius L. Population from the Anadyr River Medium Reaches in Different Intensity Fishing Conditions, Vestnik NESC FEB RAS, 3, 92-95 [In Russian].

Grunin, S. I., 2010, Population Indicators Dynamics of the Northern Pike Esox lucius L. (Esocidae) from the Anadyr River in 1971-2010, Izvestiya TINRO, 179, 4554 [In Russian].

Grunin, S. I.; Baklanov, M. A., 2004, Dimensional Variability of External Morphological Signs of Juvenile Pikes Esox lucius L., Bulletin of Perm University, Biology, 2, 99-101 [In Russian]. 
Grunin, S. I.; Shestakov, A. V., 2011, Present State of the Pike Population Esox lucius L. from the Middle Course of the Anadyr R. (Chukotka), Problems of Fisheries, 12, 3, 457-471 [In Russian].

Hansen, M. M.; Taggart, J. B.; Meldrup, D., 1999, Development of New VNTR Markers for Pike and Assessment of Variability at Di- and Tetranucleotide Repeat Microsatellite Loci, J. Fish. Biol., 55, 183-188.

Healy, J. A.; Mulcahy, M. F., 1980, A Biochemical Genetic Analysis of Populations of the Northern Pike, Esox lucius L., from Europe and North America, Ibid., $17,317-324$

Howell, N., 1989, Evolutionary Conservation of Protein Regions in the Proton Motive Cytochrome $b$ and Their Possible Roles in Redox Catalysis, J. Mol. Evol., 29, 157-169.

Irwin, D. M.; Kocher, T. D.; Wilson, A. C., 1991, Evolution of the Cytochrome $b$ Gene of Mammals, Ibid., 32, 128-144.

Ishiguro, N. B.; Miya, M.; Nishida, M., 2003, Basal Euteleostean Relationships, A Mitogenomic Perspective on the Phylogenetic Reality of the "Protacanthopterygii", Mol. Phylogenet. Evol., 27, 3, 476-488.

Kartavtsev, Yu. F., 2013, Genetic Divergence of Species and Other Taxa, Geographical Speciation and the Genetic Paradigm of Neo-Darwinism in Action, Uspekhi Sovremennoy Biologiyi, 133, 5, 419-451 [In Russian].

Kartavtsev, Y. Ph.; Park, T.-J.; Vinnikov, K. A.; Ivankov, V. N.; Sharina, S. N.; Lee, J.-S., 2007, Cytochrome b (Cyt-b) Gene Sequence Analysis in Six Flatfish Species (Teleostei, Pleuronectidae), with Phylogenetic and Taxonomic Insights, Marine Biology, 152, 757-773.

Khokhlov, Yu. N.; Khokhlova, Yu. E., 2006, Nutrition of the Northern Pike Esox lucius L. in the Middle Course of the Anadyr R. in the Autumnal Period, Vestnik NESC FEB RAS, 2, 54-58 [In Russian].

Kim, H. S.; Choi, E. S.; Shin, J. A.; Jang, Y. K.; Park, S. D., 2004, Regulation of Swi6/HPl-dependent Heterochromatin Assembly by Cooperation of Components of the Mitogen-Activated Protein Kinase Pathway and a Histone Deacetylase Clr6, J. Biol. Chem., 279, 4285042859.

Kirillov, F. Ya., 1972, Fishes of Yakutia, Moscow, Nauka [In Russian].

Lukashov, V. V., 2009, Molecular Evolution and Phylogenetic Analysis, Moscow, BINOM, Laboratory of Knowledge [In Russian].

Lunsghersgauzen, G. F., 1961, Geological History of the Middle Reaches of the Lena and Some Questions of Quaternary Deposits Stratigraphy of Eastern Siberia, $M a$ terials of All-Union Meeting on the Study of the Quarternary Period, Part 3, Moscow, AS USSR, 209-217 [In Russian].

McClellan, D. A.; Palfreyman, E. J.; Smith, M. J.; Moss, J. L.; Christensen, R. G.; Sailsbery, J. K., 2005, Physicochemical Evolution and Molecular Adaptation of the Cetacean and Artiodactyl Cytochrome b Proteins, Mol. Biol. Evol., 22, 437-455.

Miller, L. M.; Kapuscinski, A. R., 1996, Notes: Microsatellite DNA Markers Reveal New Jevels of Genetic Variation in Northern Pike, Trans. Am. Fish Soc., 125, 971-977.
Miller, L. M.; Kapuscinski, A. R., 1997, Historical Analysis of Genetic Variation Reveals Low Effective Population Size in a Northern Pike (Esox lucius) Population, Genetics, 147, 1249-1258.

Miller, L. M.; Senanan, $W ., 2003$, A Review of Northern Pike Population Genetics Research and its Implications for Management, North Am. J. Fish Managem., 23, 297-306.

Naylor, G. J.; Collins, T. M.; Brown, W. M., 1996, Hydrophobicity and Phylogeny, Nature, 373, 565-566.

Nei, M., 1987, Molecular Evolutionary Genetics, New York, Columb. Univ. Press, 512.

Nei, M.; Kumar, S., 2000, Molecular Evolution and Phylogenetic, New York, Oxford Univ. Press.

Nicod, J. C.; Wang, Y. Z.; Excoffier, L.; Largiadèr, C. R., 2004, Low Levels of Mitochondrial DNA Variation among Central and Southern European Esox lucius Populations, J. Fish Biol., 64, 1442-1449.

Novikov, A. S., 1966, Fishes of the Kolyma River, Moscow, Nauka [In Russian].

Saitou, N.; Imanishi, T., 1989, Relative Efficiencies of the Fitch-Margoliash, Maximum-Parsimony, MaximumLikelihood, Maximum-Evolution, and NeighborJoining Methods of Phylogenetic Tree Construction in Obstraining the Correct Tree, Mol. Biol. Evol., 6, 514525.

Sambrook, J.; Fritschi, E. F.; Maniatis T., 1989, Molecular Cloning: a Laboratory Manual, New York, Cold Spring Harbor Laboratory Press.

Seeb, J. E.; Seeb, L. W.; Oates, D. W.; Utter, F. M., 1987, Genetic Variation and Postglacial of Populations of Northern Pike (Esox lucius) in North America, Can. J. Fish Aquat. Sci., 44, 556-561.

Senanan, W.; Kapuscinski, A. R., 2000, Genetic Relationships Among Populations of Northern Pike (Esox lucius), Ibid., 57, 391-404.

Skog, A.; Vollestad, L. A.; Stenseth, N. C.; Kasumyan, A.; Jakobsen, K. S., 2014, Circumpolar Phylogeography of the Northern Pike (Esox lucius) and Its Relationship to the Amur Pike (E. reichertii), Frontiers Zool., 11:67, https://doi.org/10.1186/s12983-014-0067-8

Takezaki, N.; Nei, M.; Tamura, K., 2014, POPTREEW: Web Version of Poptree for Constructing Population Trees from Allele Frequency Data and Computing Some Other Quantities, Mol. Biol. Evol., 31 (6), 1622-1624, DOI: 10.1093/molbev/msu093 Advance Access Publication March 6, 2014.

Tamura, K.; Stecher, G.; Peterson, D.; Filipski, A.; Kumar, S., 2013, MEGA-6: Molecular Evolutionary Genetics Analysis Version 6.0.2.74, Ibid., 30, 2725-2729, DOI: 10.1093/molbev/mst197. Epub October 16, 2013.

Tokranov, A. M., 2004, On "Scaleless Beast" and Other Inhabitants of Kamchatka Waters, PetropavlovskKamchatsky [In Russian].

Woolley, S.; Johnson, M. J.; Smith, M. J., 2003, TreeSAAP : Selection on Amino Acid Properties Using Phylogenetic Trees, Bioinformatics, 19, 5, 671-672.

Zhukov, V. V.; Pinchuk, L. Ya.; Puminov, A. P., 1966, Paleogeography of the North-East of the Central Siberian Plateau and the Lena-Anadyr Lowland in the Cenozoic, Quaternary Period of Siberia, Moscow, Nauka, 264-272 [In Russian]. 